\title{
Pembangunan Pariwisata Baduy dan Dampaknya Terhadap Ekologi, Sosial, dan Budaya: Sebuah Studi Literatur
}

\author{
Satria Iman Prasetyo ${ }^{1}$, Muhammad Naufal Rofi ${ }^{2}$, Muhammad Basofi Firmansyah ${ }^{3}$ \\ Universitas Muhammadiyah Yogyakarta ${ }^{123}$ \\ Email: ${ }^{1}$ satriaip26@gmail.com
}

\begin{abstract}
Abstrak: Pembangunan pariwisata haruslah bersifat berkelanjutan. Hal ini bertujuan pariwisata tidak hanya dimanfaatkan oleh generasi sekarang melainkan generasi yang akan datang. WTO (World Trade Organization) menjelaskan bahwa pembangunan pariwisata berkelanjutan haruslah mengedepankan prinsip-prinsip seperti Ecological Sustainability, Social and Cultural Sustainability, dan Economic Sustainability. Metode yang digunakan dalam penelitian ini adalah studi literatur. Data yang diperoleh dikompulasi, dianalisis, dan disimpulkan sehingga mendapatkan kesimpulan mengenai topik yang diteliti. Hasil penelitian menunjukan bahwa pembangunan pariwisata di kampung adat Baduy belumlah sesuai dengan prinsip-prinsip pembangunan berkelanjutan. Pertama, secara ekologi, adanya pembangunan pariwisata justru membawa dampak terhadap ancaman destruksi lingkungan di kampung adat Baduy. Hal ini diketahui dari menumpuknya sampah plastik yang dibuang secara sembarang oleh wisatawan. Kedua, secara sosial dan budaya, adanya pembangunan pariwisata justru membawa perubahan tata nilai masyarakat Baduy dari tradisional ke modern. Ketiga, secara ekonomi, adanya pembangunan pariwisata mampu meningkatkan perekonomian masyarakat Baduy dengan membuka warung-warung di halaman rumah mereka. Meski demikian peningkatan perekonomian ini selaras dengan kerusakan lingkungan dan perubahan sosial budaya masyarakat Baduy.
\end{abstract}

Kata kunci: Pembangunan pariwisata, kampung adat Baduy, ekologi, ekonomi, sosial dan budaya

Abstract: Tourism development must be sustainable. It is intended that tourism is not only used by current generations but future generations. The WTO (World Trade Organization) explains that sustainable tourism development must prioritize principles such as Ecological Sustainability, Social and Cultural Sustainability, and Economic Sustainability. The method used in this research is literature study. The data obtained were compiled, analyzed, and concluded in order to get conclusions about the topic under study. The results showed that tourism development in the Baduy traditional village was not yet in accordance with the principles of sustainable development. First, ecologically, the existence of tourism development actually has an impact on the threat of environmental destruction in the Baduy traditional village. This is known from the accumulation of plastic waste that is disposed of arbitrarily by tourists. Second, socially and culturally, the existence of tourism development has actually brought about changes in the values of the Baduy community from traditional to modern. Third, economically, the existence of tourism development is able to improve the economy of the Baduy community by opening stalls in their yard. However, this economic increase is in line with environmental damage and changes in the socio-culture of the Baduy community.

Keywords: tourism development, Baduy traditional village, ecology, economy, social and culture 


\section{Pendahuluan}

Paper ini bertujuan untuk mengkaji dampak adanya pembangunan pariwisata terhadap ekologi, sosial budaya, dan ekonomi masyarakat Baduy. Pembangunan pariwisata tidak dibenarkan dilakukan secara sporadis, terlebih di wilayah yang memiliki adat istiadatnya tersendiri seperti di kampung adat Baduy. Sebagaimana diketahui bahwa masyarakat adat Baduy merupakan masyarakat adat bersuku sunda yang memiliki nilai-nilai kehidupan yang berbeda dengan masyarakat pada umumnya. Kehidupan masyarakat Baduy tidak lepas dari hukum adat yang mereka pegang teguh sebagai bukti kepatuhan mereka terhadap perintah leluhur. Mereka hidup sederhana, tradisional, dan lestari dengan alam. Bagi masyarakat Baduy, menjaga kelestarian alam merupakan bentuk kepatuhan terhadap adat. Selain itu, alam bagi masyarakat Baduy merupakan sumber kehidupan. Merusak alam sama saja merusak kehidupan.

Masih terjaganya kelestarian alam ditambah keunikan masyarakatnya yang masih memegang teguh adat istiadat leluhur, membuat kampung Adat Baduy menjadi objek wisata potensial yang harus dikembangkan. Namun, sebagaimana yang sudah dijelaskan sebelumnya, bahwa pembangunan pariwisata tidaklah dilakukan secara sporadis. Melainkan tetap memperhatikan kelestarian alam dan nilai-nilai kebudayaan masyarakat lokal. Hal ini perlu dilakukan agar pembangunan pariwisata tidak membawa dampak negatif baik secara ekologi maupun sosial budaya. Oleh sebab itu, pembangunan pariwisata berkelanjutan (Sustainable Tourism Development) perlu diterapkan di kampung adat Baduy dengan mengintegrasikan lingkungan fisik (place), lingkungan budaya (host community), dan wisatawan (visitor).

Untuk mencapai pembangunan pariwisata berkelanjutan, Burns dan Holder mengkonstruksikan tiga prinsip. Pertama, Ecologycal Sustainability bermakna bahwa adanya pembangunan pariwisata tidak membawa dampak terhadap rusaknya ekosistem yang telah ada. Kedua, Sosial Adaptability, bermakna bahwa masyarakat lokal mampu beradaptasi dengan kebudayaan yang berbeda dengan kebudayaan setempat. Seperti pola prilaku, gaya hidup yang modernis, dan etika. Hal ini diperlukan agar tidak terjadinya ketidak-harmonisan hubungan sosial antara wisatawan dan masyarakat lokal. Ketiga Cultural Sustainability, yang bermakna bahwa pembangunan pariwisata tidak mendegradasi nilai-nilai kebudayaan lokal. Sehingga kebudayaan tersebut dapat dipertahankan untuk generasi yang akan datang.

Diketahui bahwa pembangunan pariwisata di kampung adat Baduy merupakan upaya pemerintah Kabupaten Lebak dalam mengkonservasi alam dan budaya di kampung adat Baduy. Hal ini sebagaimana tertuang pada Perda Kabupaten Lebak Nomor 13/1990 tentang pembinaan dan pengembangan lembaga adat Baduy. Jika 
melihat tujan pemerintah setempat menjadikan kampung adat Baduy menjadi objek wisata maka pembangunan pariwisata di sana haruslah bersifat keberlanjutan dengan mengedepankan prinsip-prinsip ekologi, sosial, dan budaya. Diketahui bahwa kampung adat Baduy merupakan destinasi wisata unggulan di Kabupaten Lebak. Hal ini diketahui dari tabel 1:

Tabel 1. Data Kunjungan Wisatawan Kabupaten Lebak Per Destinasi Wisata tahun 2020

\begin{tabular}{|c|c|}
\hline Destinasi Wisata & Jumlah Wisatawan \\
\hline Pantai Sawarna & 46.503 \\
\hline Baduy & 20.319 \\
\hline Tirta Lebak Buana & 12.216 \\
\hline Pantai Cibareno & 10.395 \\
\hline
\end{tabular}

(Sumber. Dinas Pariwisata Kabupaten Lebak 2020)

Tabel 1 menunjukan, kampung Baduy masih menjadi wisata unggulan bagi wisatawan yang datang berkunjung pada tahun 2020. Lingkungan yang masih lestari dan keunikan budaya di kampung adat Baduy menjadi daya tarik tersendiri bagi wisatawan yang datang berkunjung ke Baduy. Jika pemerintah Kabupaten Lebak tidak memberikan atensi terhadap ekologi, sosial dan budaya sebagai sumberdaya yang harus di pertahankan. Maka potensi turunnya jumlah wisatawan akan terjadi. Bahkan parahnya, kerusakan alam dan pergeseran tata nilai dari masyarakat Baduy akan terjadi sebagai dampak dari adanya pembangunan pariwisata.

Berdasarkan permasalahan pembangunan pariwisata di atas, paper ini merumuskan masalah "Bagaimana pembangunan pariwisata di kampung adat Baduy?". Penelitian-penelitian sebelumnya yang memiliki relevansi dengan paper ini adalah Nurhidayati (2015), Rahmi (2016) Dewantara (2019), ketiganya menjelaskan pentingnya keterlibatan masyarakat lokal dalam pembangunan pariwisata untuk meningkatkan perekonomian dan menjaga kelestarian alam. Padahal menurut Wall, pembangunan berkelanjutan tidak hanya melihat aspek ekonomi dan ekologi, melainkan keberlanjutan budaya agar nilai-nilai kebudayaan tidak terdampak pembangunan pariwisata. Oleh sebab itu, paper ini akan melihat pembangunan pariwisata dari tiga aspek yaitu ekologi, sosial, dan budaya.

\section{Kajian Pustaka}

Penelitian terdahulu yang memiliki relevansi dengan paper yang akan di teliti dapat dijumpai dari sejumlah literatur yang ada. Menurut World Trade Organization, 
pembangunan haruslah mengedepankan prinsip-prinsip pembangunan yang mencakup diantaranya, ekologi, sosial budaya, dan ekonomi. Ketiganya penting agar kemanfaatannya dapat dirasakan untuk generasi yang akan datang. Oleh sebab itu setiap pembangunan termasuk diantaranya pembangunan pariwisata haruslah bersifat berkelanjutan. Pembangunan pariwisata berkelanjutan diartikan sebagai proses pembangunan pariwisata yang berorientasi kepada kelestarian sumberdaya yang dibutuhkan untuk pembangunan pada masa yang akan datang.

Menurut Wall (dalam Iskandar, 2011), pembangunan pariwisata berkelanjutan tidak hanya memperhatikan pada ekologi dan ekonomi saja melainkan harus memperhatikan sosial budaya juga. Karena ketiganya saling berhubungan satu dengan yang lainnya. Oleh sebab itu Suwena (dalam Anom, 2010) dalam penelitiannya memberikan syarat-syarat tercapainya pembangunan pariwisata berkelanjutan. Pertama, secara ekologi tidak menimbukan efek terhadap ekosistem setempat. Kedua, secara sosial dapat diterima oleh lingkungan sekitar/masyarakat lokal. Ketiga, secara kebudayaan dapat dterima. Keempat, secara ekonomi dapat memberikan keuntungan dan meningkatkan kesejahteraan masyarakat.

Relevan dengan itu, Burns dan Holder (dalam Anom, 2010) memberikan pengertian bahwa pembangunan pariwisata berkelanjutan haruslah mengintegrasikan lingkungan fisik, budaya, dan wisatawan. Untuk mengintegrasikan ketiganya, maka dikonstruksikan tujuh prinsip diantaranya. Pertama, memperhatikan kelestarian lingkungan. Kedua, pariwisata harus memberikan keuntungan kepada masyarakat lokal. Ketiga, adanya hubungan harmonis antara wisatawan dan masyarakat lokal. Keempat, pembangunan pariwisara harus penduli terhadap alam. Kelima, tidak adanya konflik antar masyarakat lokal dan wisatawab. Keenam, masyarakat lokal mampu beradaptasi dengan kebudayaan baru yang di bawa wisatawwan. Ketujuh, pemerintah lokal, swasta, dan LSM memiliki tugas untuk merealisasikan semuanya.

Piagam pariwisata berkelanjutan (dalam Rusito, 2017) menekankan juga bahwa pariwisata haruslah didasari kriteria yang berkelanjutan seperti di dukung oleh pembangunan ekologi jangka panjang dan pariwisata harus layak secara ekonomi serta adil secara etika dan sosial terhadap masyarakat lokal. Oleh sebab itu, konsep sustainable development meliputi tiga komponen. Pertama, ekological sustainability, yang bermakna bahwa adanya pariwisata tidak berdampak pada ekosistem setempat. Kedua, Social Adaptability yang bermakna bahwa masyarakat setempat mampu beradaptasi dengan kebudayaan baru yang dibawa oleh wisatawan. Ketiga, Cultural Sustainability yang bermakna bahwa pariwisata haruslah menjaga nilai-nilai kebudayaan lokal agar tidak terdegradasi. 
Oleh sebab itu dalam pengembangan pariwisata berkelanjutan adalah dengan pariwisata berkelanjutan berbasis masyarakat. Pada pembangunan pariwisata di kampung adat Baduy telah menerapkan konsep pembangunan pariwisata berbasis masyarakat. Penelitian Nurhidayati (2015), Rahmi (2016) menjelaskan pentingnya pentingnya keterlibatan masyarakat lokal dalam pembangunan pariwisata dalam menjaga potensi budaya atau kearifan lokal yang dimiliki oleh masing-masing daerah. Keterlibatan masyarakat lokal dalam pembangunan pariwisata, dilakukan juga oleh masyarakat adat di kampung adat Baduy. Dewantara (2019) dan Sugiwa (2015) menjelaskan pentingnya keterlibatan masyarakat lokal dalam menjaga nilai-nilai kebudayaan.

Menurut pandangan Razak (2019) mengungkapkan bahwa pembangunan pariwisata harus dikaitkan dengan karakteristik sosial ekonomi masyarakat lokal sehingga kemajuan pariwisata akan terintegrasi dengan perekoomian masyarakat lokal. Oleh sebab itu Cohen dan Uthoff (2020) menyarankan agar mengidentifikasi dan menganalisis siapa saja yang harus berpartisipasi dalam pembangunan pariwisata Pertama, penduduk setempat. Kedua, pemimpin masyarakat baik secara formal maupun non formal. Ketigaa, pejabat pemerintahan. Keempat, orang asing/swasta.

Namun, dalam konteks masyarakat adat, peran kepala suku/kepala adat sangat vital sekali. Biasanya masyarakat adat akan lebih patuh terhadap perintah kepala adatnya. oleh sebab itu, pembangunan pariwisata yang dilakukan di wilayah adat haruslah melibatkan kepala adat untuk berpartisipasi dalam pembangunan pariwisata. Tohar dan Robbins (2021) mendefinisikan kepemimpinan adat sebagai suatu aktivitas untuk mempengaruhi perilaku masyarakat agar mau diarahkan mencapai tujuan tertentu. Hal yang sama seperti yang dikatakan Max Well John (2020) bahwa kepemimpinan adalah soal bagaimana mengelola sumberdaya yang ada untuk mencapai tujuan yang di harapkan.

Dari beberapa literatur yang sudah di paparkan diatas, dapat diketahui bahwa penelitian-penelitian sebelumnya hanya menekankan pada konteks pembahasan seperti definisi pembangunan pariwisata berkelanjutan, keterlibatan masyarakat lokal, dan peran ketua adat dalam pembangunan pariwisata. Selain itu, pembangunan pariwisata yang mengedepankan prinsip ekologi, sosial dan budaya. Hanya menekankan pada pembahasan ekonomi dan ekologi, padahal ekologi, sosial dan budaya merupakan aspek penting yang tidak dipisahkan. Oleh sebab itu paper ini akan mengkaji pembangunan pariwisata di kampung adat Baduy dengan mengkaji tiga prinsip pembangunan berkelanjutan seperti ekologi, sosial dan budaya. 


\section{Metode Penelitian}

Dalam penelitian ini digunakan metode pendekatan studi literatur. Menurut Cooper (dalam Creswell, 2019) studi literatur memiliki beberapa tujuan diantaranya memberikan informasi kepada pembaca dari hasil-hasil penelitian yang sudah ada. Selain itu hasil-hasil penelitian yang sudah ada dipilih secara relevan dengan penelitian yang dilakukan, menggabungkan/menghubungkan, dan mengisis celah dalam penelitian sebelumnya.

Pengumpulan data dilakukan dengan mengumpulkan informasi dari jurnal, skripsi, buku-buku penunjang, surat kabar, dan majalah yang memiliki relevansi dengan topik penelitian yang dikaji. Setelah itu menghubungkan penelitian yang sudah ada dan menganalisis untuk mendapatkan jawaban atas permasalahan yang sedang di kaji dalam penelitian ini. Teknik analisis data adalah data yang sudah diperoleh dikompulasikan, dianalisis, dan disimpulkan sehingga mendapatkan kesimpulan mengenai topik yang diteliti.

\section{Hasil Penelitian dan Pembahasan}

\section{a. Ecologycal Sustainability}

Salah satu prinsip-prinsip pembangunan berkelanjutan adalah mengedepankan Ecologycal Sustainability atau ekologi berkelanjutan, yaitu pembangunan pariwisata di satu wilayah tidak membawa dampak negatif terhadap ekosistem setempat. Prinsip ini bukanlah tanpa tujuan melainkan menjaga kelestarian alam untuk generasi yang akan datang. Hal ini sebagaimana Burns dan Holder (dalam Anom, 2010) menjelaskan bahwa lingkungan mempunyai nilai hakiki yang berfungsi sebagai asset wisata. Pemanfaatanya tidak hanya untuk kepentingan jangka pendek melainkan untuk kepentingan generasi mendatang.

Sebagaimana yang diketahui, di jadikannya kampung adat Baduy sebagai objek wisata adalah memiliki keunggulan dari aspek lingkungannya yang masih asri. Lingkungan yang masih asri ini tidak dapat di lepaskan dari nilai-nilai kehidupan masyarakat Baduy yang menjaga kelestarian alam (Iskandar dan Supangkat, 2017) . Bagi masyarakat Baduy, menjaga kelestarian alam sama saja menjaga kehidupan. Hal ini di karenakan, keterggantungan kehidupan masyarakat Baduy terhadap hasil-hasil alam seperti padi dan kebun.

Keunggulan dari aspek lingkungan inilah yang menjadi daya tarik wisatawan untuk berkunjung ke kampung adat Baduy. Bahkan, intensitas wisatawan yang berkunjung ke kampung adat Baduy cukup tinggi dan terus mengalami peningkatan dari tahun ke tahunnya. Peningkatan wisatawan tersebut dapat di lihat pada jumlah data wisatawan yang datang ke Kampung Baduy dalam kurun empat tahun terakhir. 
Tabel 2. Data Kunjungan Wisatawan Kabupaten Lebak Per destinasi Wisata 2016-2020

\begin{tabular}{|c|c|}
\hline Tahun & Jumlah Wisatawan \\
\hline 2017 & 19.168 \\
\hline 2018 & 21.316 \\
\hline 2019 & 42.174 \\
\hline 2020 & 20.319 \\
\hline
\end{tabular}

(Sumber. Dinas Kebudayaan dan Pariwisata Kabupaten Lebak 2020)

Dari tabel di atas dapat diketahui bahwa terdapat peningkatan jumlah wisatawan dari tahun 2017 hingga 2019, terkecuali tahun 2020 yang mengalami penurunan jumlah wisatawan. Hal ini di karenakan adanya pandemi covid-19 yang mengharuskan kampung adat Baduy di tutup sementara untuk memutus rantai penyebaran virus covid-19 (Fadhil, 2020). Tingginya intensitas wisatawan tersebut, justeru membawa ancaman bagi ekosistem di kampung adat Baduy. Hal ini meningkatnya jumlah wisatawan, selaras dengan menumpuknya jumlah sampah plastik yang di buang secara sembarang oleh wisatawan. Padahal, sampah plastik memiliki dampak kerusakan yang luar biasa bagi lingkungan, karena sifatnya yang sulit terurai.

Selain tingginya intensitas wisatawan, faktor lain terjadinya penumpukan sampah di wilayah adat Baduy adalah, tidak adanya aturan adat yang mengatur tentang penanggulangan sampah plastik. Hal ini di karenakan, makanan atau minuman berkemasan plastik merupakan hal yang baru bagi masyarakat Baduy. Mereka terbiasa membungkus sesuatu dengan bahan-bahan dari alam seperti daun pisang. Inilah yang menyebabkan kebingungan dari masyarakat Baduy karena adat tidak mengatur penanggulangan sampah plastik. Alternatif yang bisa di lakukan oleh masyarakat Baduy adalah membakar sampah tersebut di pinggiran kampung adat Baduy. Namun, cara ini justru menambah persoalan baru seperti tercemarnya udara di kampung adat Baduy yang di sebabkan dari pembakaran sampah plastik (Zaenudin Ahmad, 2020).

\section{b. Economic Sustainability}

Prinsip pembangunan pariwisata berkelanjutan lainnya adalah Economic Sustainability, yaitu dari sektor ekonomi, adanya pariwisata dapat memberikan keuntungan bagi masyarakat lokal. Terlebih adanya program pemerintah melalui Program Nasional Pemberdayaan Masyarakat (PNPM) Mandiri pariwisata telah mengharuskan pembangunan pariwisata dengan melibatkan masyarakat lokal. Keterlibatan ini menurut Demartono(dalam Anom, 2010) bertujuan untuk meningkatkan peran dan partisipasi masyarakat agar memperoleh keuntungan ekonomi, sosial maupun budaya dari pembangunan tersebut. 
Adanya pembangunan pariwisata telah mendongkrak perekonomian masyarakat Baduy. Hal ini dikarenakan, masyarakat Baduy memanfaatkan tingginya intensitas wisatawan yang datang berkunjung dengan membuka usaha warung yang menjajakan makanan dan minuman di halaman rumah mereka. Selain, makanan dan minuman, masyarakat Baduy menjual hasil-hasil alam berupa madu odeng, jahe dan kerajinan tangan khas baduy lain. Hadirnya wisatawan, merubah sistem perdagangan mereka yang sebelumnya dilakukan dengan cara menjemput bola atau menemui pembeli di luar kampung adat Baduy (Sugiwa, 2015). Namun, dengan adanya kegiatan wisata, mereka tidak perlu lagi melakukan perjalanan keluar kampung adat Baduy untuk menemui pembeli. Karena mereka bisa menjual barang dagangan mereka di halaman rumah mereka.

\section{c. Social And Cultural Sustainabilty}

Selain prinsip ekologi, prinsip lain yang harus di perhatikan dalam pembangunan pariwisata berkelanjutan adalah social adaptability, yaitu pembangunan pariwisata di wilayah tertentu tidak menimbulkan konflik sosial atau ketidak harmonisan dengan masyarakat lokal. Hal ini sebagaimana Suwena (dalam Anom, 2010) menjelaskan bahwa pembangunan pariwisata secara sosial dapat diterima oleh masyarakat lokal, yaitu mengacu pada kemampuan penduduk lokal untuk menyerap usaha pariwisata (industri dan wisatawan) tanpa menimbulkan konflik sosial.

Pernyataan tersebut jika di kaitkan dengan pembangunan pariwisata di kampung adat Baduy sangat relevan. Hal ini dikarenakan, pembangunan pariwisata di kampung adat Baduy tidak bisa dilepaskan dari keterlibatan masyarakat Baduy dalam pembangunan pariwisata. Keterlibatan ini sebagai upaya dari Pemerintah Kabupaten Lebak untuk menjaga nilai-nilai budaya masyarakat Baduy dari pengaruh dunia luar melalui wisatawan, dan meningkatkan perekonomian masyarakat lokal. Hal ini terbukti, sejak adanya kegiatan wisata di kampung adat Baduy, masyarakat Baduy mulai menggantungkan kehidupannya melalui sektor pariwisata melalui membuka usaha warung-warung di halam rumah mereka (Ashdiana, 2016).

Merebaknya warung-warung di kampung adat Baduy sebagai pemanfaatan masyarakat lokal terhadap kegiatan pariwisata, merupakan bentuk pergeseran nilai-nilai kehidupan masyarakat Baduy dari tradisional ke modern. Hal ini dapat di lihat dari aneka makanan dan minuman yang mereka jual berbahan plastik. Sebagaimana yang di jelaskan sebelumnya, penggunaan plastik merupakan hal yang baru dan belum ada adat yang mengatur tentang cara penanggulangannya.

Perubahan ini sebagaimana di jelaskan oleh Horton (2010)bahwa pariwisata dalam beberapa kasus telah menarik masyarakat ke arah konsumerisme, materialisme, dan komodifikasi. Selaras denga horton, Cohen menjelaskan perubahahan tata nilai masyarakat Baduy dari tradisional ke modern di sebabkan karena tingginya intensitas wisatawan yang 
notabene memiliki kebudayaan yang berbeda mengunjungi, berprilaku dan berinteraksi dengan masyarakat akan berdampak pada pergeseran tata nilai seperti efek peniruan, marginalisasi, dan komodifikasi budaya.

\section{Pembahasan}

Masyarakat baduy merupakan masyarakat adat yang hidup secara komunal dan memegang teguh aturan adat mereka yang sebut sebagai "pikukuh karuhun". Kehidupan mereka harmoni dengan alam, hal ini terlihat dari prilaku mereka sehari-hari yang menggunakan alat-alat tradisional untuk menghindari kerusakan lingkungan yang disebabkan dari penggunaan alat-alat modern (Suparmini, Setyawati dan Sumunar, 2013). Alam bagi masyarakat baduy merupakan sumber kehidupan yang wajib dijaga kelestariannya. Kehidupan masyarakat baduy sangat bergantung pada alam seperti hasil alam dan perkebunan. Oleh sebab itu merusak alam saja dengan merusak kehidupan.

Sikap untuk senantiasa menjaga alam, terlihat pada semboyan mereka yang menggunakan bahasa lokal "gunung ulah dilebur, lebak ulah diruksak" yang berartikan, gunung tidak boleh dihancurkan dan lebak/dataran tidak boleh dirusak. Semboyan ini bermakna bahwa manusia hidup berdampingan dengan alam, dan Tuhan telah menciptakan alam untuk pemenuhan kebutuhan semua manusia. Ambilah hasil alam sesuai kebutuhan dan tidak berlebihan (Septiana, 2020). Makna semboyan tersebut menampar kehidupan manusia modern yang tidak pernah puas dengan apa yang ia punya. Kerusakan alam terjadi ketika manusia tidak pernah puas dan selalu mempunyai hasrat untuk mengeksploitasi alam tanpa perhitungan. Alhasil eksploitasi yang dilakukan secara brutal ini mengakibatkan kerusakan lingkungan dan berdampak pada bencana alam.

Ketika pemerintah Kabupaten Lebak, menetapkan kampung adat baduy menjadi desa wisata. Pembangunan pariwisata mulai gencar dilakukan untuk mendongkrak wisatawan datang berkunjung. Pembangunan infrastruktur mulai gencar dilakukan seperti pembangunan penginapan, sarana air bersih, listrik, dan komunikasi (Ashdiana, 2016). Meskipun pembangunan tersebut dilakukan diluar wilayah adat, namun tetap saja yang menjadi objek wisata adalah kampung adat baduy. Kampung adat baduy yang masih asri dan kehidupan masyarakat yang masih mempertahankan adat leluhurnya menjadi daya tarik tersendiri bagi wisatawan untuk berkunjung. Hal inilah yang melatarbelakangi pemerintah menerapkan konsep pariwisata berbasis alam di kampung adat baduy.

Menurut WTO (World Trade Organization) pembangunan pariwisata haruslah mengedepankan pembangunan-pembangunan yang mencakup Ecological Sustainability, Social and Cultural Sustainability, dan Economic Sustainability (Anom, 2010). Tujuan dari mengedepankan ketiga aspek tersebut adalah agar pembangunan pariwisata tidak hanya di nikmati kemanfaatannya oleh generasi sekarang, melainkan generasi yang akan datang. Selaras dengan itu, Burns dan Holder (dalam Anom, 2010) menjelaskan pembangunan 
pariwisata haruslah mengintegrasikan lingkungan fisik (place), lingkungan budaya (host community), dan wisatawan (visitor) untuk mencapai pembangunan yang berkelanjutan.

Tujuan Pembangunan pariwisata di wilayah adat Baduy oleh Pemerintah Kabupaten Lebak adalah sebagai upaya untuk mengkonservasi budaya dan lingkungan melalui pariwisata. Hal ini sebagaimana di ketahui dalam Perda Kabupaten Lebak Nomor 13/1990 tentang pembinaan dan pengembangan lembaga adat Baduy (Zaenudin Ahmad, 2020). Kelestarian alam di kampung adat baduy yang masih asri dan keunikan masyarakatnya yang masih memegang teguh kehidupan tradisional dengan kebudayaanya, menjadi latar belakang kampung adat Baduy di jadikan desa wisata berbasis alam dan budaya.

Dari maksud dan tujuan Pemerintah Kabupaten Lebak menjadikan kampung adat Baduy sebagai desa wisata, maka pembangunan pariwisata di kampung adat Baduy haruslah bersifat berkelanjutan dengan mengedepankan tiga prinsip Ecological Sustainability, Social and Cultural Sustainability, dan Economic Sustainability. Ketiga prinsip pembangunan tersebut adalah sebagai upaya Pemerintah Kabupaten Lebak untuk meminimalizir dampak dari adanya kegiatan pariwisata. Namun, jika ketiga prinsip pembangunan tersebut di kaitkan dengan pembangunan pariwisata yang ada di kampung adat Baduy, realitanya justru bertolak belakang.

Namun, pembangunan pariwisata di kampung adat Baduy membawa ancaman serius bagi ekosistem alam yang mereka jaga. Hal ini terlihat dari menumpuknya sampah plastik yang di buang secara sembarang oleh wisatawan yang berkunjung. Padahal, sampah plastik sangatlah merusak bagi lingkungan alam karena sifatnya yang sulit terurai. Situasi ini di perparah oleh ketiadaanya aturan adat yang mengatur cara penanggulangan sampah plastik bekas pakai. Ini karena, sampah plastik tergolong ke dalam benda-benda modern dan tabu di pergunakan oleh masyarakat Baduy. Tentu saja jika di biarkan dalam jangka waktu yang lama, sampah plastik ini akan merusak ekosistem kampung Baduy itu sendiri.

Namun, jika melihat dalam sudut pandang ekonomi, adanya pariwisata justru berdampak pada peningkatan perekonomian mereka. Hal ini dikarenakan tingginya intensitas wisatawan yang berkunjung di manfaatkan oleh masyarakat Baduy untuk mencari usaha tambahan dengan membuka warung- warung di depan rumah mereka. Persoalannya adalah bukan berada pada peningkatan perekonomian masyarakat lokal, melainkan dari barang dagangan yang mereka jajakan berupa makanan dan minuman berkemasan plastik.

Alasan mereka menjual barang dagangan berkemasan plastik karena mengikuti selera konsumen atau wisatawan yang notabene merupakan masyarakat modern. Umumnya wisatawan kurang tertarik dengan makanan-makanan yang di sajikan secara tradisional seperti makanan yang di bungkus dengan daun pisang atau dalam bahasa lokal di sebut sebagai pais. Ini menandakan bahwa masyarakat Baduy itu sendiri telah menjadi salah satu faktor penyebab menumpuknya sampah plastik di lingkungan adat mereka. 
Merebaknya warung-warung yang di buka oleh masyarakat Baduy, menandakan bahwa telah terjadinya perubahan nilai-nilai kehidupan dari tradisional ke modern. Masyarakat Baduy yang sebelumnya menggantungkan kehidupan lewat hasil-hasil alam, kini dengan adanya pembangunan pariwisata telah mengalihkan mata pencahariaan mereka yang lebih bergantung kepada sektor pariwisata. Hal ini sebagaimana di jelaskan oleh Horton (2010)bahwa pariwisata dalam beberapa kasus telah menarik masyarakat ke arah konsumerisme, materialisme, dan komodifikasi. Padahal menurut Wall, pembangunan pariwisata tidak hanya menekankan pada ekonomi dan ekologi saja melainkan berkelanjutan dalam hal kebudayaan. Karena kebudayaan merupakan sumber penting dalam pariwisata.

Dari beberapa persoalan-persoalan di atas sebagai dampak dari adanya pembangunan pariwisata, dapat di katakan bahwa pembangunan pariwisata di Kampung adat Baduy. dapat di katakan bahwa pembangunan pariwisata di Kampung Adat Baduy hanya menguntungkan pada sektor ekonomi. Namun belum memperhatikan dua aspek prinsip pembangunan berkelanjutan seperti ekologi dan sosial budaya. Padahal, kedua aspek ini merupakan daya tarik dari pariwisata di kampung adat Baduy. Oleh sebab itu, langkah alternatif yang bisa di lakukan adalah dengan mengintegrasikan lingkungan fisik, lingkungan budaya, dan wisatawan. Untuk mengonstruksikan hal tersebut, diperlukan keterlibatan antar pemerintah lokal, swasta, dan masyarakat lokal yang bekerja sama untuk merealisasikannya.

\section{Kesimpulan}

Pembangunan pariwisata haruslah bersifat berkelanjutan, agar kemanfaatannya tidak hanya di rasakan oleh generasi saat ini melainkan generasi yang akan datang. Untuk itu WTO (World Trade Organization) menjelaskan pembangunan pariwisata haruslah mengedepankan pembangunan-pembangunan yang mencakup Ecological Sustainability, Social and Cultural Sustainability, dan Economic Sustainability. Namun, pembangunan pariwisata di Kampung adat Baduy belumlah sesuai dengan ketiga prinsip pembangunan pariwisata berkelanjutan. Hal ini di karenakan pertama. secara ekologi, adanya kegiatan pariwisata justru menimbulkan tumpukan sampah yang di buang secara sembarang oleh wisatawan yang datang berkunjung. Tentu saja, penumpukan sampah ini sangat mengan cam bagi ekosistem lingkungan di kampung adat Baduy. Kedua, pembangunan pariwisata di kampung adat Baduy berdampak pada peningkatan ekonomi masyarakat lokal. Ketiga, peningkatan ekonomi tersebut, harus di bayar mahal dengan adanya perubahan nilai-nilai masyarakat baduy dari tradisional ke modern. 


\section{Daftar Pustaka}

Anom, I. P. (2010). Pariwisata Berkelanjutan dalam Pusaran Krisis Global. Udayana university Press.

Ashdiana, I. M. (2016). Pariwisata Baduy Bisa Mendunia, Asal... Kompas.Com. https://travel.kompas.com/read/2016/07/24/134600527/Pariwisata.Baduy.Bisa.Me ndunia.Asal.?page=all

Creswell, J. W. (2019). Research Design. Pustaka Pelajar.

Dewantara, M. handijaya. (2019). Pemberdayaan Masyarakat dalam Pengembangan Wisata Kampung Kampung Baduy- Banten. Journal of Tourismpreneurship, Culinary, Hospitaly, Convention, and Event Management, 2(1), 1-20.

Fadhil, A. I. (2020). Baduy dan Pembangunan Pariwisata Berbasis Alam. IB Times. https://ibtimes.id/baduy-dan-pembangunan-pariwisata-berbasis-alam/

Firdaus, M. N., Budiaman, \& Herminasari, N. S. (2020). Peran Komunitas Pramuwisata Baduy Luar dalam Mempertahankan Kearifan Lokal. Jurnal Edukasi IP, 4(1), 1-10.

Horto, L. . (2010). Buying up Nature: Economic and Social Impact of Costa Rica's Ecotourism Boom. Latin American Perspectives.

Iskandar, J., \& Iskandar, B. S. (2011). Agroekosistem Orang Sunda. Buku Kiblat Utama Press. Iskandar, J., and Iskandar, B.S. 2017. Various Plants of Traditional Rituals: Ethnobotanical Research Among the Baduy Community. Biosaintifika 9 (1).

Iskandar, Johan., \& Supangkat, B. (2017). Kearifan Ekologi Orang Baduy dalam Konservasi Padi Dengan “'Sistem Leuit.'” Jurnal Biodjati, 2(1), 1-14.

Kurnialam, A. (2021). Pemkab Lebak Ingin Pertahankan Wisata Baduy. Replubika.Co.Id. https://republika.co.id/berita/daerah/jawa-barat/qd3an9384/pemkab-lebak-inginpertahankan-wisata-baduy

Nurhidayati, E. S. (2015). Community Based Tourism (CBT) sebagai Pendekatan Pembangunan Pariwisata Berkelanjutan. Media Masyarakat Kebudayaan Dan Politik, 10(3), 1-11.

Prasetyo, S. I. (2019). Komunikasi politik masyarakat baduy.

Rahmi, S. A. (2016). Pembangunan pariwisata dalam perspektif kearifan lokal. Jurnal Reformasi, 6(1), 1-11.

Rusito. (2017). Penyelenggaraan Kewenangan Desa Adat (Studi Kasus di Desa Kanekes Suku Baduy Kabupaten Lebak Provinsi Banten). Jurnal Ilmiah Niagara, IX(2), 1-18.

Septiana, T. W. (2020). 4 sifat teladan suku Baduy yang bisa Anda terapkan di kehidupan sehari-hari. Antara News. https://lifestyle.kontan.co.id/news/4-sifat-teladan-sukubaduy-yang-bisa-anda-terapkan-di-kehidupan-sehari-hari?page=all

Sugiwa, I. (2015). Pengembangan Pariwisata Berbasis Keunikan Penduduk di Wilayah Banten (Studi di Wilayah Baduy). Jurnal Penelitian Dan Pengambangan Humaniora, 12(2), 1-11.

Suparmini, Setyawati, S., \& Sumunar, D. R. (2013). Pelestarian Lingkungan Masyarakat Baduy Berbasis Kearifan Lokal. Jurnal Penelitian Humaniora, 18(1), 1-15.

Zaenudin Ahmad. (2020). Desa Baduy: Wilayah Adat yang Dipaksa Jadi Objek Wisata. Tirto.Id. https://tirto.id/desa-baduy-wilayah-adat-yang-dipaksa-jadi-objek-wisatafSzE 